\title{
EFFECT OF DIFFERENT TEMPERATURE AND MOISTURE ON DEVELOPMENT OF IN VITRO DERIVED BANANA PLANTLETS
}

\author{
Hasan Pinar ${ }^{1, *}$, Nadide Kılınc ${ }^{2}$, Aydın Uzun ${ }^{1}$ \\ ${ }^{1}$ Erciyes University, Department of Horticulture, Kayseri, Turkey \\ ${ }^{2}$ Nefir Agriculture, Mersin, Turkey
}

Current Trends in

Natural Sciences

\begin{abstract}
Seedling development is important in vitro production. Sometimes, lots of in vitro plant materials have died under acclimatization. Humidity and temperature are important factor during acclimatization of banana plantlets. But these factors have varied as banana cultivars. In this study, it is investigated effect of different temperature and molsture on development of in vitro derived banana seedlings belong to two banana cultivars. In present study, it is aimed to determine of effect of different temperatures and moisture on development of in vitro derived banana seedlings. Rooted seedlings of two different banana cultivar which grown in Turkey which about 5-6 cm height were transferred to peat: petlite media and they were grown under 22, 24, $26{ }^{\circ} \mathrm{C}$ temperature and 70\%, 80\% and 90\% humidity. As obtained results, Nefir Deniz cultivar had highest plant height under $80 \%$ humidty $+26{ }^{\circ} \mathrm{C}(8,26 \mathrm{~cm})$ and lowest plant height was under $90 \%$ humidty $+22{ }^{\circ} \mathrm{C}(6.24 \mathrm{~cm})$. Nefir AZ banana cultivar had highest plant height under $70 \%$ humidty $+22{ }^{\circ} \mathrm{C}$ $(9.53 \mathrm{~cm})$ and lowest plant height was under $80 \%$ humidty $+24{ }^{\circ} \mathrm{C}(6.12 \mathrm{~cm})$. Obtained results show that different humidity and temperature conditions should applied for different banana cultivar seedling acclimatization.
\end{abstract}

Keywords: banana, in vitro seedling acclimatization.

\section{INTRODUCTION}

Seedling development is important in vitro production. Sometimes, lots of in vitro plant materials have died under acclimatization. Humidity and air temperature is mentioned as a key factor in controlling during acclimatization of banana plantlets, prior to in vivo transplantation. On a commercial scale, banana plantlets have been produced by micropropagation through plant tissue culture, which is successfully implemented. Normally, the environments in in vivo are quite different when compared to in vitro conditions, in terms of relative humidity (RH), constant temperature, air ventilation, nutrient levels, etc (Kozai et al., 1997; Chen, 2004; Hazarika, 2006). In vitro acclimatization, or hardening, is one of the main processes in the production of healthy plantlets before their transplantation to in vivo (Pospísilová et al., 1999a). But these factors have varied as banana cultivars. There are many techniques for controlling the RH in the culture vessel of plant tissue culture, such as, saturated salt addition to the culture chamber and increasing the air ventilation rate (Cui et al., 2000; Cha-um et al., 2003; Shim et al., 2003). Acclimatized plantlet adaptation is an important mechanism in the transplanting process of plant micropropagation, relating to survival percentage, growth and development (van Huylenbroeck et al., 1998; van Huylenbroeck et al., 2000; Kadleček et al., 2001; Fila et al., 2006). Healthy, acclimatized plantlets 
have been identified using physiological characteristics including chlorophyll content, chlorophyll a fluorescence parameters, $\mathrm{CO} 2$ assimilation, net photosynthetic rate $(\mathrm{Pn})$, stomatal conductance (gs) and transpiration rate $(\mathrm{E})$, which have been demonstrated in many plants such as orchids (Jeon et al., 2005), Calathea louisae (van Huylenbroeck et al., 2000), tobacco (Pospíšilová et al., 1999b; Kadleček et al., 2001), Spathiphyllum floribundum (van Huylenbroeck et al., 1998), strawberry (Borkowska, 2001), grapevine (Carvalho and Amâncio, 2002a; Fila et al., 2006) and chestnut (Carvalho and Amâncio, 2002b). Banana plantlet (Musa sp.) acclimatization can be divided into two phases. In the first, in vitro plantlets are transferred to controlled environments (greenhouse or box shade, under the conditions of $20^{\circ} \mathrm{C}$ to $28^{\circ} \mathrm{C}, 80$ to $90 \% \mathrm{RH}$, and $70 \%$ shade cloth) for a three to six-week period. In the second phase, plantlets are shifted to trays, pots or bags, under $50 \%$ shade, in a temperature range from $18^{\circ} \mathrm{C}$ to $34^{\circ} \mathrm{C}$, and a relative humidity higher than $75 \%$, for a gradual hardening (Souza et al., 1997; Hoffmann, 2002). When plantlets reach 25-30 cm height they are considered acclimated and become available to the market (Silva et al., 1999). In this study, it si investigated effect of different temperature and moisture on development of in vitro derived banana seedlings belong to two banana cultivars.

\section{MATERIALS AND METHODS}

Two different banana cultivars (Nefir Deniz and Nefir AZ which improved at banana breeding program as new banana cultivar in Turkey as plant material.

Thirty-six in vitro derived banana seedlings were used for each application with three replications (12x3=36 seedlings). Rooted seedlings which about 5-6 cm height were transferred to peat: petlite media and they were grown under $22^{\circ} \mathrm{C}, 24^{\circ} \mathrm{C}, 26^{\circ} \mathrm{C}$ temperature and $70 \%, 80 \%$ and $90 \%$ humidity. Plant diameter $(\mathrm{cm})$ and plant height $(\mathrm{cm})$ measured weekly. Obtained results were analyzed using EXEL program. Also, data analyzed using JUMP statistic program.

\section{RESULTS AND DISCUSSIONS}

The results are given in Table 1, Table 2. According to the findings obtained, Plant height and plant diameter measured in Nefir Deniz Banana cultivar for 4 weeks and in the last week, scoring was done for the visual scale. Graph created with the findings obtained in the 4th week and In Nefir Deniz banana cultivar, plant height is obtained in the 4th week at the lowest $90 \%$ humidity $+22{ }^{0} \mathrm{C}$ $(6,24 \mathrm{~cm})$ temperature and humidity application, the highest was obtained from $80 \%$ Humidity +26 ${ }^{0} \mathrm{C}(8.26 \mathrm{~cm})$ temperature application.

On the other hand, plant height and plant diameter were measured for 4 weeks in Nefir AZ Banana variety and scoring was done for visual scale in the last week. Graph was created with the findings obtained in the 4th week (Table 2) and In Nefir AZ banana cultivar, plant height is obtained in the 4th week at the lowest $80 \%$ humidity $+24{ }^{0} \mathrm{C}(6.12 \mathrm{~cm})$ temperature and humidity application, while the highest is obtained from $70 \%$ Humidity $+22{ }^{0} \mathrm{C}(9.53 \mathrm{~cm})$ temperature application. The application of $80 \%$ Moisture $+26{ }^{0} \mathrm{C}$, which is the most successful application in the Nefir Deniz banana variety, also gave a successful result in the Nefir AZ banana variety compared to other applications. In addition, the data obtained from the study were subjected to variance analysis using JUMP statistical software. The differences were found significant in terms of the characteristics examined between cultivars and applications. Statistically significant characters at $\mathrm{p}<0.05$ level were listed according to the Minimum Significant Difference (OEF) method, and the level of difference and significance was revealed (Table 3, Table 4). 


\section{Current Trends in Natural Sciences}

Vol. 9, Issue 17, pp. 216-221, 2020

https://doi.org/10.47068/ctns.2020.v9i17.027

Current Trends in Natural Sciences (on-line)

ISSN: 2284-953X

Current Trends in Natural Sciences (CD-Rom) ISSN: 2284-9521

ISSN-L: 2284-9521

ISSN-L: 2284-9521

Table 1. Data obtained from the effect of Nefir Deniz, banana variety on seedling growth under 3 different temperature $\left(22^{\circ} \mathrm{C}, 24^{\circ} \mathrm{C}, 26^{\circ} \mathrm{C}\right)$ and 3 different humidity $(70 \%, 80 \%, 90 \%)$ conditions

\begin{tabular}{|c|c|c|c|c|c|c|c|c|c|}
\hline Cultrlvar & \multicolumn{2}{|c|}{ 1. week } & \multicolumn{2}{|c|}{ 2. week } & \multicolumn{2}{|c|}{ 3. week } & \multicolumn{3}{|c|}{ 4. week } \\
\hline Nef'lr Deniz & $\begin{array}{c}\text { Plant } \\
\text { helght(cm) }\end{array}$ & $\begin{array}{c}\text { Plant } \\
\text { dlamater }(\mathrm{cm})\end{array}$ & $\begin{array}{c}\text { Plant } \\
\text { helght(cm) }\end{array}$ & $\begin{array}{c}\text { Plant } \\
\text { dlamater( } \mathrm{cm})\end{array}$ & $\begin{array}{c}\text { Plant } \\
\text { helght }(\mathrm{cm})\end{array}$ & \begin{tabular}{|c|} 
Plant \\
dlamater $(\mathrm{cm})$
\end{tabular} & $\begin{array}{c}\text { Plant } \\
\text { helght(cm) }\end{array}$ & $\begin{array}{c}\text { Plant } \\
\text { dlamater }(\mathrm{cm})\end{array}$ & scale(1-5) \\
\hline $90 \%+22^{\circ} \mathrm{C}$ & 4.00 & 0.31 & 4.60 & 0.35 & 5.44 & 0.39 & 6.24 & 0.44 & 3 \\
\hline $90 \%+24^{\circ} \mathrm{C}$ & 7.54 & 0.36 & 6.98 & 0.41 & 6.26 & 0.42 & 6.58 & 0.46 & 3 \\
\hline $90 \%+26^{\circ} \mathrm{C}$ & 5.74 & 0.37 & 6.24 & 0.39 & 6.34 & 0.45 & 6.94 & 0.48 & 4 \\
\hline $80 \%+22^{\circ} \mathrm{C}$ & 5.72 & 0.31 & 6.16 & 0.44 & 6.58 & 0.49 & 7.32 & 0.59 & 4 \\
\hline $80 \%+24^{\circ} \mathrm{C}$ & 6.78 & 0.42 & 7.22 & 0.46 & 7.44 & 0.48 & 7.54 & 0.57 & 4 \\
\hline $80 \%+26^{\circ} \mathrm{C}$ & 5.76 & 0.51 & 6.54 & 0.57 & 7.32 & 0.60 & 8.26 & 0.63 & 5 \\
\hline $70 \%+22^{n} \mathrm{C}$ & 4.90 & 0.3 .5 & 5.44 & 0.45 & 5.80 & 0.50 & 6.42 & 0.51 & 3 \\
\hline $70 \%+24^{\circ} \mathrm{C}$ & 4.63 & 0.30 & 5.78 & 0.41 & 6.23 & 0.44 & 7.08 & 0.49 & 4 \\
\hline $70 \%+26^{\circ} \mathrm{C}$ & 6.32 & 0.31 & 5.90 & 0.42 & 5.98 & 0.45 & 6.76 & 0.49 & 4 \\
\hline Max & 7.54 & 0.51 & 7.22 & 0.57 & 7.44 & 0.60 & 8.26 & 0.63 & 5.00 \\
\hline MIn. & 4.00 & 0.30 & 4.60 & 0.35 & 5.44 & 0.39 & 6.24 & 0.44 & 3.00 \\
\hline
\end{tabular}

Table 2. Data obtained from the effect of Nefir AZ banana variety on seedling growth under 3 different temperature $\left(22{ }^{\circ} \mathrm{C}, 24^{\circ} \mathrm{C}, 26^{\circ} \mathrm{C}\right)$ and 3 different humidity $(70 \%, 80 \%, 90 \%)$ conditions

\begin{tabular}{|c|c|c|c|c|c|c|c|c|c|}
\hline Cultivar & 1 & weck & 2 & weck & 3. & week & & 4. wed & \\
\hline Nefir AZ & $\begin{array}{c}\text { Plant } \\
\text { height(cm) }\end{array}$ & $\begin{array}{c}\text { Plant } \\
\text { diamater }(\mathrm{cm})\end{array}$ & $\begin{array}{c}\text { Plant } \\
\text { height }(\mathrm{cm})\end{array}$ & $\begin{array}{c}\text { Plant } \\
\text { diamater }(\mathrm{cm})\end{array}$ & $\begin{array}{c}\text { Plant } \\
\text { height }(\mathrm{cm})\end{array}$ & \begin{tabular}{|c|} 
Plant \\
diamater $(\mathrm{cm})$
\end{tabular} & $\begin{array}{c}\text { Plant } \\
\text { height }(\mathrm{cm})\end{array}$ & $\begin{array}{c}\text { Plant } \\
\text { diamater }(\mathrm{cm})\end{array}$ & Scale(1-5) \\
\hline $90 \%+22^{\circ} \mathrm{C}$ & 4.78 & 0.32 & 5.64 & 0.36 & 6.10 & 0.42 & 6.68 & 0.49 & 4 \\
\hline $90 \%+24^{\circ} \mathrm{C}$ & 5.08 & 0.37 & 6.76 & 0.42 & 8.34 & 0.44 & 9.44 & 0.52 & 5 \\
\hline $90 \%+26{ }^{\circ} \mathrm{C}$ & 4.68 & 0.33 & 5.84 & 0.41 & 6.90 & 0.46 & 7.92 & 0.52 & 4 \\
\hline $80 \%+22{ }^{\circ} \mathrm{C}$ & 4.72 & 0.29 & 5.62 & 0.32 & 5.80 & 0.39 & 7.64 & 0.43 & 4 \\
\hline $80 \%+24^{\circ} \mathrm{C}$ & 4.28 & 0.32 & 5.08 & 0.42 & 5.46 & 0.43 & 6.12 & 0.46 & 3 \\
\hline $80 \%+26{ }^{\circ} \mathrm{C}$ & 6.14 & 0.32 & 7.14 & 0.40 & 7.68 & 0.48 & 8.98 & 0.52 & 5 \\
\hline $70 \%+22^{\circ} \mathrm{C}$ & 7.10 & 0.42 & 7.93 & 0.47 & 9.07 & 0.50 & 9.53 & 0.59 & 5 \\
\hline $70 \%+24{ }^{\circ} \mathrm{C}$ & 5.96 & 0.29 & 6.60 & 0.43 & 6.96 & 0.46 & 7.50 & 0.50 & 4 \\
\hline $70 \%+26{ }^{\circ} \mathrm{C}$ & 4.40 & 0.27 & 5.14 & 0.36 & 5.86 & 0.43 & 6.64 & 0.52 & 4 \\
\hline Max. & 7.10 & 0.42 & 7.93 & 0.47 & 9.07 & 0.50 & 9.53 & 0.59 & 5.00 \\
\hline Min. & 4.28 & 0.27 & 5.08 & 0.32 & 5.46 & 0.39 & 6.12 & 0.43 & 3.00 \\
\hline
\end{tabular}

Table 3. Statistical analysis table of the effects of different applications on seedling growth (Plant height) in Nefir Deniz and Nefir AZ banana varieties

\begin{tabular}{|c|c|c|c|c|c|c|}
\hline \multicolumn{7}{|c|}{ Plant həight(cm) } \\
\hline \multirow{2}{*}{ Cultivar } & \multirow{2}{*}{ Humidty } & \multicolumn{3}{|c|}{ Air temperature } & \multirow{3}{*}{$\begin{array}{c}\text { Mean. } \\
\text { (Humldty) } \\
\mathbf{8 . 0 1 3}\end{array}$} & \multirow{2}{*}{$\begin{array}{c}\text { Mean } \\
\text { (Cultlvar) }\end{array}$} \\
\hline & & $22{ }^{\circ} \mathrm{C}$ & $24{ }^{0} \mathrm{C}$ & $26{ }^{\circ} \mathrm{C}$ & & \\
\hline \multirow{4}{*}{$\begin{array}{l}\text { Nefir } \\
\text { Denlz }\end{array}$} & $90 \%$ & $6.680 \mathrm{~cd}$ & $9.440 \mathrm{a}$ & $7.920 \mathrm{a}-\mathrm{d}$ & & \multirow{3}{*}{7.827} \\
\hline & $80 \%$ & 7.64 a-d & $6.120 \mathrm{~d}$ & $8.980 \mathrm{ab}$ & 7.580 & \\
\hline & $70 \%$ & $9.520 \mathrm{a}$ & $7.50 \mathrm{a}-\mathrm{d}$ & $6.640 \mathrm{~cd}$ & 7.887 & \\
\hline & Mean & 7.947 & 7.687 & 7.847 & & \\
\hline \multirow{4}{*}{ Nefir AZ } & $90 \%$ & $6.240 \mathrm{~cd}$ & $6.940 \mathrm{~b}-\mathrm{d}$ & $6.580 \mathrm{~cd}$ & 6.587 & \multirow{3}{*}{7.002} \\
\hline & $80 \%$ & $8.260 \mathrm{a}-\mathrm{c}$ & $7.540 \mathrm{a}-\mathrm{d}$ & $7.320 \mathrm{~b}-\mathrm{d}$ & 7.707 & \\
\hline & $70 \%$ & $6.760 \mathrm{~cd}$ & $6.960 \mathrm{~b}-\mathrm{d}$ & $6.420 \mathrm{~cd}$ & 6.713 & \\
\hline & Mean & 7.087 & 7.147 & 6.773 & & \\
\hline
\end{tabular}

According to the results of statistical analysis, Variety, Temperature * Humidity and Humidity * Variety * Temperature applications were found important in terms of plant height (Table 5).

Patel et al. (2015) reported that even though there is not much difference in the survival rate of plants emerging from tissue culture of different banana varieties in Coco peat environment, it varies according to cultivars (Grand Naine (87.5\%), Mahalaxmi (85.6\%), Shrimanti (81.9\%), and Basarai (83.7\%). Scaranari et al. (2009) investigated the effect of 3 different shades of red (70\%, 50\%, $30 \%)$ and 1 shade of black (50\%) on the development of banana seedlings belonging to the Grand nain cultivar and the most successful result was black (50\%) and red. They obtained from $70 \%$ application. The objective of this study was to evaluate the development of pre-acclimatized banana 


\section{Current Trends in Natural Sciences}

Vol. 9, Issue 17, pp. 216-221, 2020

https://doi.org/10.47068/ctns.2020.v9i17.027

Current Trends in Natural Sciences (on-line)

ISSN: 2284-953X

Current Trends in Natural Sciences (CD-Rom)

ISSN: 2284-9521

ISSN-L: 2284-9521

ISSN-L: 2284-9521

plantlets cv. Pioneira (Musa sp., Group AAAB) obtained from tissue culture. Seedlings were multiplied in five subcultures (30 days each), on MS medium supplemented with $5 \mathrm{mg}$.L-1 BA (benzyl aminopurine), solidified with agar gel, pH 5.8, under 20 hours photoperiod, 2,000 lux of light intensity and temperature of $25^{ \pm} 2^{\circ} \mathrm{C}$. The in vitro rooting was performed on MS medium. Plantlets were pre-acclimatized for 30 days in a greenhouse, under controlled conditions of temperature and irrigation. These plantlets, $4.8^{ \pm} 1.5 \mathrm{~cm}$ high, were then transferred to plastic bags containing organic substrate. Growth and development of the plantlets were evaluated under several conditions: greenhouse, humid chamber in greenhouse, screen house, humid chamber in screen house, under tree canopy, humid chamber under tree canopy and in-field conditions. A completely randomized design was used with five replications, each replicate containing 10 plantlets. Evaluations of plantlet development were performed at 60 and 120 days after transplanting. All treatments showed $100 \%$ plantlet growth, except for the direct field transplanting (39.7\%). The plantlet development was similar in greenhouse, screen house, and under tree canopy conditions. The proposed system shows feasibility for use in long-distance distribution of micro propagated plantlets (Silva et al. 1997).

Table 4. Statistical analysis of the effects of different applications on seedling growth (Plant diameter) in Nefir Deniz and Nefir AZ banana varieties

\begin{tabular}{|c|c|c|c|c|c|c|}
\hline \multicolumn{7}{|c|}{ Plant diameter $(\mathrm{cm})$} \\
\hline \multirow{2}{*}{ Cultivar } & \multirow{2}{*}{ Humiditiy } & \multicolumn{3}{|c|}{ Air Temperature } & \multirow{2}{*}{$\begin{array}{c}\text { Mean. } \\
\text { (Humiditiy) }\end{array}$} & \multirow{2}{*}{$\begin{array}{c}\text { Mean } \\
\text { (Cultivar) }\end{array}$} \\
\hline & & $22{ }^{\circ} \mathrm{C}$ & $24^{\circ} \mathrm{C}$ & $26^{\circ} \mathrm{C}$ & & \\
\hline \multirow{4}{*}{$\begin{array}{l}\text { Nefir } \\
\text { Denlz }\end{array}$} & $90 \%$ & 0.490 & 0.520 & 0.520 & $0.510 \mathrm{bc}$ & \multirow{3}{*}{0.506} \\
\hline & $80 \%$ & 0.430 & 0.460 & 0.520 & $0.470 \mathrm{bc}$ & \\
\hline & $70 \%$ & 0.590 & 0.500 & 0.520 & $0.537 \mathrm{ab}$ & \\
\hline & Mean & 0.503 & 0.493 & 0.520 & & \\
\hline \multirow{4}{*}{ Nefir AZ } & $90 \%$ & 0.440 & 0.480 & 0.460 & $0.460 \mathrm{c}$ & \multirow{3}{*}{0.520} \\
\hline & $80 \%$ & 0.630 & 0.570 & 0.590 & $0.597 a$ & \\
\hline & $70 \%$ & 0.490 & 0.510 & 0.510 & $0.503 \mathrm{bc}$ & \\
\hline & Mean & 0.520 & 0.520 & 0.520 & & \\
\hline
\end{tabular}

Table 5. F-values of some growth characteristics of banana cultivars

\begin{tabular}{|l|c|c|c|c|}
\hline \multicolumn{4}{|c|}{ F Value } \\
\hline & Degree of freedom & Plant height & Plant diameter & \\
\hline Cultivar & 1 & $5.793^{*}$ & 0.507 & \\
\hline Humidity & 2 & 0.447 & 2.018 & \\
\hline Temperature & 2 & 0.121 & 0.147 & \\
\hline Humidty*Cultivar & 2 & 1.973 & $7.703^{*}$ & \\
\hline Temperature*Cultivar & 2 & 0.205 & 0.147 & \\
\hline Temperature*Humidty $^{*}$ & 4 & $3.553^{*}$ & 0.498 & \\
\hline Humidty* ${ }^{*}$ Cultivar* $^{*}$ Temperature & 4 & $2.518^{*}$ & 1.001 & \\
\hline
\end{tabular}

In present study, three different humidity and temperature were applied at two different banana cultivars and differences were obtained between seedling development of banana cultivars with regard to temperature and humidity. Also it was determined differences among applications as statistically. When differences between banana cultivars, the best application banana cultivar seedlings was $80 \%$ humidity $+26{ }^{0} \mathrm{C}$ temperature for Nefir Deniz and $70 \%$ humidty $+24{ }^{0} \mathrm{C}$ temperature for Nefir AZ. As our observation at open field and greenhouse conditions, Nefir AZ 
banana cultivar was more tolerant than Nefir Deniz banana cultivar with regard to chilling. Therefore, the reaction to the humidity and temperature difference between the two banana varieties may therefore have occurred. As a result of present study, a protocol was established for seedling development at appropriate temperature and humidity after tissue culture for both types of bananas.

\section{CONCLUSIONS}

The most suitable temperature and humidity protocol for the development of seedlings extracted from the tissue culture of Nefir Deniz banana variety is the application of $80 \%$ Humidity $+26{ }^{0} \mathrm{C}$ temperature. And also, The most suitable temperature and humidity protocol for the development of seedlings extracted from the tissue culture of Nefir Deniz banana variety is $70 \%$ Humidity $+22{ }^{0} \mathrm{C}$ temperature application.

\section{REFERENCES}

Borkowska, B. (2001) Morphological and physiological characteristics of micropropagated strawberry plants rooted in vitro or ex vitro. Sci Hort 89, 195-206.

Carvalho LC, Amâncio S (2002a) Antioxidant defence system in plantlets transferred from in vitro to ex vitro: effects of increasing light intensity and CO2 concentration. Plant Sci 162, 33-40.

Carvalho, L.C., Amâncio, S. (2002b) Effect of ex vitro conditions on growth and acquisition of autotrophic behaviour during the acclimatisation of chesnut regenerated in vitro. Sci Hort 95, 151-164.

Cha-um, S., Mosaleeyanon, K., Supaibulwatana, K., Kirdmanee, C. (2003) A more efficient transplanting system for Thai neem (Azadirachta siamensis Val.) by reducing relative humidity.Sci Asia 29, 189-196.

Cui, Y.C., Hanh, E.J., Kozai, T., Paek, K.Y. (2000) Number of air exchange, sucrose concentration, photosynthetic photon flux, and different in photoperiod and dark period temperature affect growth of Rehmannia glutinosa plantlets in vitro. Plant Cell Tiss Org Cult 62, 219-226.

Fila, G., Badeck, F.W., Meyer, S., Cerovic, Z., Ghashghaie, J. (2006) Relationships between leaf conductance to CO2 diffusion and photosynthesis in micropropagated grapevine plants, before and after ex vitro acclimatization. $J$ Exp Bot 57, 2687-2695.

Hazarika, B.N. (2006) Morpho-physiological disorders in in vitro culture of plants. Sci Hort 108, 105-120.

Hoffmann, A. (2002). Aclimatação de mudas produzidas in vitro e in vivo. [Seedling acclimatization produced in vitro and in vivo]. Informe Agropecuário, 23, 21-24.

Jeon, M.W., Ali, M.B., Hahn, E.J., Paek, K.Y. (2005) Effects of photon flux density on the morphology, photosynthesis and growth of a CAM orchid, Doritaenopsis during postmicropropagation acclimatization. Plant Growth Regul $45,139-147$.

Kadleček, P., Tichá, I., Haisel, D., Čapková, V., Schäfer, C. (2001) Importance of in vitro pretreatment for ex vitro acclimatization and growth. Plant Sci 161, 695-701.

Kozai, T., Kubota, C., Jeong B.R. (1997) Environmental control for the large-scale production of plants through in vitro techniques. Plant Cell Tiss Organ Cult 51:49-56 Chen C (2004). Humidity in plant tissue culture vessels. Biosyst Engineer 88, 231-241 p.543-554, 1999.

Patel, S.R., Narwade, A.V., Khatri, R.T., Singh, M.,, Pradhan, S., Sagar K. Jadav and Vivek N. Zinzala, (2015). Acclimatization of banana tissue plantlets (Musa paradisiaca) of various genotypes in poly house using different potting cultures. International Journal of Tropical Agriculture, Vol. 33, No. 4.

Pospíśilová, J., Synková, H., Haisel, D., Čatský, J., Wilhelmová, N. (1999b) Effect of elevated CO2 concentration on acclimation of tobacco plantlets to ex vitro conditions. J Exp Bot 50, 119-126.

Pospíśilová, J., Tichá, I., Kadleček, P., Haisel, D., Plzákov,á Š. (1999a) Acclimatization of micropropagated plants to ex-vitro conditions. Biol Plant 42, 481-497.

Scaranari, C., Paulo Ademar Martins LealII; Paulo Mazzafera (2009). Shading and periods of acclimatization of micropropagated banana plantlets cv. Grande Naine Sci. agric. (Piracicaba, Braz.) vol.66 no.3 Piracicaba MaylJune 2009.

Shim S.W., Hahn E.J., Paek K.Y. (2003) In vitro and ex vitro growth of grapevine rootstock '5BB' as influenced by number of air exchanges and the presence or absence of sucrose in culture media. Plant Cell Tiss Org Cult 75, $57-62$. 
Sılva, D.S., Bosısıo A., Boscarol B., Beltzer, A., Amsler, G.P. Aclimatação de mudas de bananeira (Musa spp.) "Prata"(AAB) em diferentes substratos [Acclimatization of banana (Musa spp.) "Prata" (AAB) seedlings on different substrates]. Ceres Magazine, v.46.

Silva, S., Oliveira, R. P., de Matos, A. P., Silva Neto, S., Prazeres, A. G., \& Oliveira, C. A. P. (1997). Development of pre-acclimatized banana plantlets obtained from tissue culture. In II International Symposium on Banana: I International Symposium on Banana in the Subtropics 490, 195-200.

Souza, A.S. Dantas, J.L.L.; Souza, F.V.D. Cordeıro, Z.J.M.; Sılva Neto, S.P. Propagação. In: Alves, E.J. (Org.) (1997) Banana culture: technical, socioeconomic and agro-industrial aspects. Cruz das Almas: EMBRAPA-CNPMF, 151-195.

van Huylenbroeck, J.M., Piqueras, A., Debergh, P.C. (1998) Photosynthesis and carbon metabolism in leaves formed prior and during ex vitro acclimatization of micropropagated plants. Plant Sci 134, 21-30.

van Huylenbroeck, J.M., Piqueras, A., Debergh, P.C. (2000) The evolution of photosynthetic capacity and the antioxidant enzymatic system during acclimatization of micropropagated Calathea plants. Plant Sci 155, 59-66. 